\title{
KONSUMSI DAN KOEFISIEN CERNA SERAT KASAR DOMBA LOKAL SUPLEMENTASI TEPUNG DAUN WARU
}

\section{CONSUMPTION AND DIGESTIBILITY OF CRUDE FIBER LOCAL SHEEP SUPPLEMENTED WITH HIBISCUS LEAF MEAL}

\author{
E Tri Wahyu Utami'1a, M Bata1 ${ }^{1}$, dan S Rahayu
}

${ }^{1}$ Jurusan Peternakan Fakultas peternakan Universitas Jenderal Soedirman jl. Dr. Soeparno No 60, Karangwangkal, Purwokerto Utara, Banyumas, Kode Pos 53122

aKorespondensi: Efrilia tri Wahyu Utami, E-mail: efrillia7@gmail.com

(Diterima oleh Dewan Redaksi: $\mathrm{xx}-\mathrm{xx}-\mathrm{xxxx}$ )

(Dipublikasikan oleh Dewan Redaksi: $\mathrm{xx}-\mathrm{xx}-\mathrm{xxxx}$ )

\begin{abstract}
The aim of this research was to find the optimum dose of hibiscus leaf meal (HLM) with ammoniated rice straw contain with probiotics on the consumption and digestibility of crude fiber of local sheep. This research used 12 male local sheep around two-years old. The research used an experimental method using a completely randomized design (CRD) with 3 treatments and repeated 4 times. The supplementation of HLM in concentrates of $0 \%, 0,24 \%$ and $0,48 \%$ from dry matter concentrates for W0, W1 and W2, respectivefly. The variables measured are crude fiber consumption and digestibility coefficient using the total collection method. Variance analysis showed that increasing the dose of HLM had a significant effect $(\mathrm{P}<0.5)$ and caused a quadratic response on crude fiber consumption and digestibility coefficient. The lowest crude fiber consumption and digestibility each achieved at the dose of HLM was $0.22 \%$ and $0.19 \%$. Based on the results of the research the recommended dosage of HLM to increased consumption and crude fiber digestibility coefficient was $0.48 \%$.
\end{abstract}

Keywords: Saponin, Daun Waru, Serat Kasar, Domba Lokal

\begin{abstract}
ABSTRAK
Penelitian bertujuan untuk menemukan dosis optimum pemberian tepung daun waru (TDW) pada pakan domba lokal dengan jerami padi amoniasi yang diberi tambahan probiotik terhadap konsumsi dan kecernaan serat kasar. Penelitian ini menggunakan 12 ekor domba lokal jantan berumur sekitar 2 tahun. Penelitian menggunakan metode eksperimental dirancang sesuai Rancangan Acak Lengkap (RAL) dengan 3 perlakuan dan diulang sebanyak 4 kali. Suplementasi TDW pada konsentrat adalah 0\%, 0,24 dan 0,48\% berdasarkan bahan kering konsentrat pada masing-masing perlakuan W0, W1 dan W2. Peubah yang diukur adalah konsumsi dan koefisien cerna serat kasar menggunakan metode koleksi total. Analisis variansi menunjukan bahwa peningkatan dosis TDW berpengaruh nyata $(\mathrm{P}<0,5)$ secara kuadrater terhadap konsumsi dan koefisien cerna serat kasar. Konsumsi dan koefisien cerna serat kasar paling rendah dicapai pada dosis TDW masing-masing adalah $0,22 \%$ dan 0,19\%. Berdasarkan hasil penelitian dosis TDW yang direkomendasikan untuk meningkatkan konsumsi dan koefisien cerna serat kasar adalah 0,48\%.
\end{abstract}

Kata kunci: Saponin, Daun Waru, Serat Kasar, Domba Lokal

E Tri Wahyu Utami, M Bata, dan S Rahayu . 2020. Konsumsi Dan Koefisien Cerna Serat Kasar Domba Lokal Suplementasi Tepung Daun Waru. Jurnal Peternakan Nusantara 2(2): 159 - 166.

\section{PENDAHULUAN}

Gas metana merupakan produk samping dari proses fermentasi karbohidrat pada rumen. Proses pembentukan gas metan menyebabkan ternak kehilangan energi pakan (Sukmawati et al, 2011). Semakin banyak gas metana yang terbentuk maka dapat 
menurunkan produktivitas ternak. Upaya untuk menanggulangi hal tersebut salah satunya dengan menurunkan populasi protozoa karena protozoa bersimbiosis dengan bakteri metanogenik (penghasil gas metan). Penggunaan saponin pada pakan dapat menurunkan populasi protozoa dalam rumen (Suhartati et al., 2011; Krisnawan, 2015; Hidayah, 2016). Saponin membentuk ikatan dengan sterol yang terdapat pada permukaan membran protozoa, sehingga menyebabkan pecahnya dinding sel protozoa (Arum et al, 2013). Penurunaan populasi protozoa berdampak pada peningkatan bakteri selulolitik, sehingga degradasi serat kasar pakan menjadi lebih optimal dan konsumsi serat kasar meningkat. Nutigusti (2011) menyatakan bahwa penambahan tepung daun waru dosis $0,32 \%$ pada pakan sapi lokal berbasis jerami padi amoniasi mampu meningkatakan kecernaan serat kasar. Penggunaan jerami padi amoniasi memiliki kelemahan yaitu tingginya amonia yang lepas ke lingkungan sehingga menyebabkan bau yang menyengat. Hal tersebut menyebabkan palatabilitas pakan menurun serta berefek pada penurunan konsumsi pakan. Penambahan probiotik pada jerami padi amoniasi membantu menurunkan bau amonia. Bakteri mengikat $\mathrm{N}$ NH3 yang terdapat pada jerami padi amoniasi, sehingga amonia yang lepas ke lingkungan berkurang. Kandungan serat kasar jerami Jerami padi amoniasi mengalami penurunan setelah diberi tambahan probiotik dari $29,5 \%$ menjadi 29,2\%. Namun demikan, informasi seberapa banyak dosis penggunaan tepung daun waru untuk meningkatakan konsumsi dan kecernaan serat kasar pakan domba lokal berbasis jerami padi amoniasi yang diberi tambahan probiotik belum diketahui.

\section{MATERI DAN METODE}

\section{Materi}

Materi yang digunakan dalam penelitian adalah 12 ekor domba lokal jantan yang berumur sekitar 2 tahun yang berasal dari Kabupaten Cilacap. Domba ditempatkan secara acak dalam kandang metabolis dengan ukuran kandang individu $1,5 \times 0,75 \mathrm{~m}$.

\section{Perlakuan}

Perlakuan yang diuji adalah dosis tepung daun waru membentuk 3 perlakuan W0 $(0 \%)$, W1 $(0,24 \%)$ dan $\mathrm{W} 2(0,48 \%)$ yang masing-masing akan diulang sebanyak 4 kali.

\section{Rancangan Percobaan}

Penelitian menggunakan metode eksperimental dirancang sesuai Rancangan Acak Lengkap (Steel dan Torrie, 1993).

\section{Peubah yang Diamati}

Peubah yang diamati dalam penelitian adalah konsumsi dan kecernaan serat kasar menggunakan metode koleksi total (Khan et al., 2003).

\section{Analisis Data}

Data yang diperoleh dianalisis dengan sidik ragam (ANOVA) dan jika perlakuan berpengaruh nyata terhadap peubah yang diamati maka analisis dilanjutkan dengan orthogonal polinomial.

\section{Prosedur Pelaksanaan}

Daun waru yang digunakan adalah daun waru kecil yang diambil dari sekitar daerah Banyumas, dikeringkan lalu digiling sampai berbentuk tepung untuk dicampur dalam konsentrat. Kandungan nutrien tepung daun waru yaitu bahan kering 95,5\%, lemak kasar $4,6 \%$, serat kasar 20,61\%, protein kasar $15,74 \%$, dan total digestible nutrient 17,74\%.

Tahap preliminari dilakukan selama 14 hari kemudian dilanjutkan dengan adaptasi pakan selama 20 hari. Ternak diberi pakan pukul 07.00 dan 15.00. Pakan diberikan dalam bentuk konsentrat dan jerami padi amoniasi. Konsentrat yang diberikan $4 \%$ dari bobot badan. Kandungan nutrien konsentrat yaitu bahan kering 88,65\%, lemak kasar 13,36\%, serat kasar 23,07\%, protein kasar 9,03\%, dan total digestible nutrient $74,58 \%$. Jerami padi amoniasi dan air minum diberikan secara adlibitum. Kandungan nutrien jerami padi amoniasi yaitu bahan kering 31,29\%\%, lemak kasar 1,56\%, serat kasar 29,5\%, protein kasar $8,13 \%$, dan total digestible nutrient $46,65 \%$. Jerami padi diamoniasi menggunakan $16 \%$ air, $5 \%$ urea, dan $2,5 \%$ onggok dan disemprot dengan probiotik probiotik $0,5 \%$ sebelum diberikan pada ternak. Probiotik yang digunaka 
mengandung Azotobacter parpalii, Bacillus pumilus, Bacillus stearothermophyllus, Bacillus lentus, Bacillus cereus, Bacillus laterosporus, Bacillus licheniformes, Corynebacterium pseudodiphteriticum, Lactobacillus sp., Micrococcus varians, Pseudomonas fluorescens, Sarcina lutea, Staphylococcus epidermis, Streptococcus thermophyllus, S. cereviseae, Phicia anomela dengan kepadatan mikroba $1,49 \times 10^{7} \mathrm{CFU} / \mathrm{g}$ bakteri, $4,50 \times 10^{4} \mathrm{CFU} / \mathrm{g}$ yeast.

Koleksi dilakukan selama 5 hari menggunakan metode koleksi total (Khan et. al., 2003). Feses disemprot dengan formalin setiap 4 jam. Pakan, sisa pakan dan feses dikoleksi setiap pagi hari sebelum pemberian pakan, ditimbang dan langsung dimasukan kedalam dioven. Serat kasar dianalisis menggunakan prosedur AOAC (1990).

\section{HASIL DAN PEMBAHASAN}

Analisis variansi menunjukan bahwa penambahan tepung daun waru berpengaruh nyata $(\mathrm{P}<0.05)$ terhadap konsumsi serat kasar pakan. Hasil yang sama ditunjukan pada penelitian Rodríguez et al., (2014) bahwa campuran Enterolobium cyclocarpum dan Leucaena leucocephala yang juga mengandung saponin pada pakan domba berpengaruh nyata $(\mathrm{P}<0,05)$ terhadap konsumsi pakan. Namun, hasil yang berbeda ditunjukan pada penelitian Darnawan (2018) bahwa penambahan ekstrak bunga waru (50 ppm dan $100 \mathrm{pm}$ ) dengan bahan pembawa dedak padi pada pakan domba lokal dengan rasio hijauan dan konsentrat 40:60 tidak berpengaruh nyata $(\mathrm{P}>0,05)$ terhadap konsumsi serat kasar pakan. Perbedaan ini terjadi karena pada penelitian tersebut penambahan saponin menggunakan bahan pembawa, sehingga tidak memberikan pengaruh nyata.

Analisis variansi menunjukan bahwa penambahan tepung daun waru berpengaruh nyata $(\mathrm{P}<0.05)$ terhadap koefisien cerna serat kasar pakan. Hasil penelitian ini sesuai dengan penelitian Nutigusti dkk. (2013) bahwa penambahan tepung daun waru berpengaruh nyata $(\mathrm{P}<0,05)$ terhadap kecernaan serat kasar. Sebaliknya, hasil yang berbeda ditunjukan pada penelitian Salimah (2010) bahwa penambahan ektrak metanol lerak taraf $0,03 \%$ dan $0,08 \%$ dalam bentuk pakan blok pada sapi PO tidak berpengaruh $(\mathrm{P}>0,05)$ terhadap kecernaan serat kasar pakan. Perbedaan ini terjadi karena agen defaunasi diberikan pada penelitian tersebut dalam bentuk pakan blok dan saponin yang terkonsumsi sangat tergantung pada frekuensi ternak menjilat pakan blok tersebut sehingga kurang berengaruh.

Berdasarkan uji orthogonal polinomial peningkatan dosis tepung daun waru menghasilkan respon konsumsi dan kecernaan serat kasar secara kuadrater dengan konsumsi dan kecernaan serat kasar terendah masingmasing dicapai pada dosis tepung daun waru 0,22\% dan 0,19\%. Pelakuan W0 menghasikan rataan konsumsi dan kecernaan serat kasar masing-masing sebesar 238,06 g/BK dan 60, $11 \%$. Peningkatan dosis tepung daun waru mula-mula menyebabkan penurunan kecernaan serat kasar sampai pada rataan koefisien cerna paling rendah yaitu 57,89\% dengan penambahan tepung daun waru pada dosis 0,19\%. Penurunan kecernaan serat kasar ini terjadi karena konsentrat yang dikonsumsi tinggi yaitu sebesar 81\% sedangkan jerami padi amoniasi hanya $19 \%$ dari total pakan yang dikonsumsi. Kondisi ini menyebabkan protozoa mati sebelum didefaunasi karena diduga $\mathrm{pH}$ rumen menjadi asam. Hal ini sesuai dengan pendapat Patra dan Saxena (2009) bahwa imbangan konsumsi antara hijauan dan konsentrat sangat berpengaruh terhadap efektivitas penggunaan saponin.

Dosis tepung daun waru rendah pada rumen yang tinggi asam laktat mengganggu stabilitas rumen dan berpengaruh terhadap penurunan kecernaan serat kasar. Kecernaan serat kasar yang rendah menyebabkan laju digesta rumen lebih lama, sehingga mengakibatkan penurunan konsumsi serat kasar sampai 185 $\mathrm{g} / \mathrm{BK}$ pada dosis tepung daun waru $0,22 \%$. Usman (2015) pakan yang dengan kecernaan rendah menyebabkan laju digesta rumen menjadi lebih lama dan memperlambat laju pengosongan rumen sehingga menurunan konsumsi pakan.

Konsumsi serat kasar kembali meningkat sampai sebesar 262,69 g pada dosis tepung daun waru $0,48 \%$ sejalan dengan meningkatnya kecernaan serat kasar yaitu sebesar 62,8\%. Peningatan kecernaan serat kasar merupakan indikasi bahwa bakteri mampu mencerna serat kasar lebih baik. Peningatan kecernaan serat kasar karena adanya peran flavonoid dalam tepung daun. Flavonoid berperan dalam peningkatan 
populasi bakteri pengguna laktat seperti Megasphaera elsdenii (Oskoueian et al., 2013; Bata dan Rahayu, 2017). Peningkatan bakteri pengguna laktat menstimulasi pertumbuhan bakteri selulolitik, sehingga lebih mampu mengkonsumsi jerami padi amoniasi. Hal ini terbukti dengan peingkatan konsumsi jerami padi amoniasi sebesar $23 \%$, sedangkan pada W0 dan W1 hanya 19\%.

\section{KESIMPULAN DAN IMPLIKASI}

\section{Kesimpulan}

Suplementasi tepung daun waru (Hibiscus tiliaces) dengan dosis 0,48\% pada konsentrat efektif untuk meningkatakan konsumsi dan kecernaan serat kasar pakan domba lokal

\section{Implikasi}

Perlu adanya penelitian lebih lanjut untuk mengetahui interaksi penggunaan probiotik dan tepung daun waru (Hibiscus tiliaceus) terhadap konsumsi dan kecernaan serat kasar pakan domba lokal.

\section{DAFTAR PUSTAKA}

Arum ISR, MB. 2013. Pengaruh Pemberian Ekstrak Daun Waru (Hibiscus Tiliaceus) Pada Pakan Sapi Potong Lokal Terhadap Produksi Vfa Total dan $\mathrm{NH}_{3}$ Secara In Vitro. Jurnal Ilmiah Peternakan, 1(1), 31-38.

Association of Official Analytica Chemists. (1999). Official Methods of Analysis of The Association Analytical Chemist. Virginia: AOAC, Inc.

Barros-Rodríguez MA, Solorio-Sánchez FJ, SandovalCastro CA, Ahmed AMM, Rojas-Herrera R, Briceño-Poo EG, ,Ku-Vera, J. C. 2014. Effect of intake of diets containing tannins and saponins on in vitro gas production and sheep performance. Animal Production Science.

Bata M, Rahayua S. 2017. Evaluation of Bioactive Substances in Hibiscus tiliaceus and its Potential as a Ruminant Feed Additive. Current Bioactive Compounds.

Darnawan A. 2018. Pengaruh Penggunaan Bahan Pembawa Dan Dosis Ekstrak Bunga Waru
(Hibiscus Tiliaceus) Terhadap Konsumsi Dan Kecernaan Serat Kasar Pakan Domba Lokal.

Hidayah N. 2016. Pemanfaatan Senyawa Metabolit Sekunder Tanaman (Tanin dan Saponin) dalam Mengurangi Emisi Metan Ternak Ruminansia. Jurnal Sain Peternakan Indonesia.

Khan RU, Naz S, Dhama K, Karthik K, Tiwari R, Abdelrahman MM, Alhidary IA, Zahoor A. 2016. Review Article Direct-Fed Microbial: Benefical Application, Modes of Action and Prospect as a Safe Tool for Enchancing Ruminant Production Safeguarding Health. International Journal of Pharmacology, 12(3), 220-231.

Krisnawan N, Sudarman A, Jayanegara A, Widyawati Y. 2015. Efek Senyawa Saponin pada Sapindus rarak dengan Pakan Berbasis Jerami Padi dalam Mitigasi Gas Metana. Jurnal Ilmu Pertanian Indonesia.

Nutigusti PMB, BR. 2013. Pengaruh Penambahan Tepung Daun Waru (Hibiscus tiliaceus) dalam Ransum Sapi Lokal Berbasis Jerami Padi Amoniasi terhadap Kecernaan Protein Kasar dan Serat Kasar. Jurnal Ilmiah Peternakan, 1(2), 669-676.

Oskoueian E, Abdullah N, Oskoueian A. 2013. Effects of flavonoids on rumen fermentation activity, methane production, and microbial population. BioMed Research International.

Patra AK, Saxena J. 2009. The effect and mode of action of saponins on the microbial populations and fermentation in the rumen and ruminant production. In Nutrition Research Reviews.

Salimah A. 2010. Kecernaan Nutrien Dan Neraca Nitrogen Sapi Peranakan Ongole Yang Mendapat Pakan Blok Mengandung Ekstrak Metanol Lerak (Sapindus rarak). http://repository.ipb.ac.id/handle/1234567 $89 / 62964$

Steel RG, Torrie. 1993. Prinsip dan Prosedur Statistika Suatu Pendekatan Biometrik. Gramedia.

Suharti S, Astuti DA, Wina E, Toharmat T. 2011. Rumen microbial population in the in vitro fermentation of different ratios of forage and concentrate in the presence of whole lerak (Sapindus Rarak) fruit extract. AsianAustralasian Journal of Animal Sciences. 
Sukmawati NS, Permana IG, Thalib A, Kompiang S. 2011. Pengaruh Complete Rumen Modifier (CRM) dan Calliandra calothyrus terhadap Produktivitas dan Gas Metan Enterik pada Kambing Perah. Jurnal Ilmu Ternak Dan Veteriner, 16(3), 173-183.
Usman Y. 2015. Perbedaan Laju Alir Partikel Pakan Berbagai Pakan Serat dalam Sistem Rumen Sapi. Jurnal Agripet. 